\title{
CONDITION MONITORING AND ANALYSIS OF DEVELOPMENT IN WINTER CROPS OF WATER EROSION PROCESSES USING REMOTE SENSING TECHNOLOGIES
}

\author{
Alexander Esaulko ${ }^{1}$, Maxim Sigida ${ }^{1}$, Evgeny Golosnoy ${ }^{1}$, Sergey Antonov ${ }^{2}$, Olga Lobankova $^{1}$ \\ ${ }^{1}$ Stavropol State Agrarian University, Russia; \\ ${ }^{2}$ North - Caucasian Federal Scientific Agrarian Center, Russia
}

aesaulko@yandex.ru, sigida@list.ru,golosnoi@mail.ru,antonov_serg@mail.ru,mamasontik@bk.ru

\begin{abstract}
The article presents the results of water erosion monitoring, which was carried out in 2015 on the territory of the agricultural landscapes of the Stavropol Territory using the methods of the Earth's remote sensing and geo-information technologies. A digital elevation model was taken as a basis and watercourses were modeled in the study area. As a result of the imposition, the received model and the identified erosion processes, and their coincidence was established in individual areas, which indicates their high degree of erosion hazard, a total of 382326 hectares of such territories were identified. In these territories, the existing anti-erosion carcass is either completely destroyed or ineffective. In this regard, it is necessary to conduct an inventory of forest shelter strips to assess their effectiveness and develop measures for erosion control of the territory. Different types of degradation in varying degrees reduce the productivity of agricultural crops. Salinity and alkalinity decrease it by $55 \%$ to the greatest extent, water erosion $-19 \%$, deflation $-13 \%$, waterlogging $-6 \%$. It has been established that water erosion as a whole along the region by 2026 can lead to a loss of 700 thousand tons of grain of the main crop in the region, winter wheat. Modern technologies, such as space imagery and GIS technologies, allow for effective and efficient detection and analysis of erosion-hazards. The combination of high-resolution remote sensing and medium resolution data has shown maximum efficiency for analyzing the development of linear water erosion processes. The development of a comprehensive program of anti-erosion measures will allow to reach up to $10 \%$ of the future harvest in the Stavropol Territory.
\end{abstract}

Keywords: erosion, GIS technology, monitoring, vegetation index.

\section{Introduction}

In the Stavropol Territory, the land area is 6,616 thousand hectares, of which $92.3 \%$ is agricultural land, which is represented by a complex and diverse landscape structure. In total, there are 24 landscapes in the region belonging to various provincial groups: forest-steppe, steppe, semi-desert, foothill and mid-mountain landscapes. The soil cover is represented by two zones: chestnut and chernozem. Climatic conditions in the region are not uniform, they vary from extremely dry with an annual precipitation of $387 \mathrm{~mm}$, to unstable wet - $665 \mathrm{~mm}$ [1-6].

Currently, the problem of land degradation in the world is one of the most acute and requires close attention. The territory of the Stavropol region is characterized by a high degree of agricultural development, which, against the background of extremely heterogeneous soil and climatic conditions, causes a change in the state of land resources $[7 ; 8]$.

The following types of soil degradation are most common in the region: salinization, water erosion, alkalinity, deflation, waterlogging, rockiness, waterlogging $[9 ; 10]$.

Remote sensing data are currently relatively accessible, visual and most reliable cartographic information reflecting constantly changing real conditions. For a qualitative assessment of the particular area vegetation a normalized vegetation index NDVI is used.

Also, based on the results of the NDVI index, it is possible to obtain data for use in calculating estimates and predictions of the yield and productivity, degree of disturbance and damage from various natural and man-made disasters, accidents, etc. [11;12].

\section{Materialsandmethods}

The goal of the research is to monitor the status and analysis of the water erosion processes development in winter crops using remote sensing technologies.

To achieve this goal it is necessary to solve the problems:

1. study the dynamics of changes in the vegetative index of winter wheat plants;

2. analyze the development of water erosion processes on the territory of agricultural landscapes based on remote sensing data. 
Studies were conducted on the territory of the Stavropol region, which is located in the Central Ciscaucasia, which significantly affects its natural conditions and soil cover. Central Ciscaucasia has the following natural physical-geographical boundaries: in the north and northeast - the Manych valley, in the east - the Khalynsky abrasive scarp of the Caspian (roughly along the meridian of $45^{\circ} \mathrm{E}$ ), in the west - the meridional section of river Kuban and the western slope of the Stavropol Upland $\left(41^{\circ} \mathrm{E}\right)$, in the south there are foothill plains and uplands of the Caucasus. The territory of the Central Ciscaucasia is distinguished by a complex geological and geomorphological structure. According to the structure of the surface, it represents the sloping plains of the foothills of the Caucasus, dissected by the valleys of the rivers Kuban, Kuma, Zelenchuk and their tributaries. The main geomorphological district of the region and its core is the Stavropol Plateau.

The use of data from remote sensing of the Earth, the use of modern technologies in agriculture are mainly aimed at solving such tasks as inventory of farmlands, identifying areas of erosion, waterlogging and other negative processes. For our research it was important to observe the change in the NDVI index, which is a normalized relative vegetation index (vegetative index). The objects of the research were the lands occupied by winter crops, various administrative-territorial units of the Stavropol Territory, the analysis of which was carried out in the period 2017-2018.

For a detailed study of the change dynamics in the vegetation index during the study period, we used the statistical data obtained by meansof the VEGA-Science service (http://sci-vega.ru/). To ensure that the readings remain relevant and accurate, the determination of the values was made every final week of the month throughout the study period. In the process a detailed analysis was conducted between each period of obtaining updated data, as well as the rationale for any change recorded in the range of the NDVI values [13;14].

Development analysis of the linear water erosion processes was carried out using the methods of the territory remote sensing among which the following were used: atmospheric, geometric and radiometric correction of satellite images; synthesizing multispectral images; deciphering by direct interpretation of the signs, creation of a digital elevation model. For spatial analysis the GIS technology methods were used: overlay, vectorization, construction of buffer zones, object geometry analysis, zone statistics, spatial sampling, modeling of watercourses in the territory and assessment of their intensity by the Strahler method. To analyze the anti-erosion efficiency of the existing forest landfills of the Stavropol Territory, we used the transformed horizontal index of Kolupyak boundary (1973). Also during the study mathematical-statistical and cartographic methods were used.

It is customary to distinguish between two stages of development of the erosion linear forms in the aspect of remote diagnostics of linear erosion processes: erosion scar or rut; erosion gully and ravine.

To analyze the development of water erosion processes on the territory of agricultural landscapes requires creation of an extensive database of spatial and thematic information. Effectively this task can be solved by geographic information systems (GIS) and Earth remote sensing data obtained from modern spacecrafts.

In connection with the active introduction of remote sensing techniques based on recording and analyzing the reflectivity of objects, it is possible to monitor areas of significant size and to get an objective view of the current state of the soil cover.

\section{Results and discussion}

For a visual perception of the vegetation index dynamics for 2018, in comparison with 2017 in the territory of the Stavropol region, you can examine the indicators reflected in the presented graph (Fig. 1).

So, in the initial periods of the research (January 2018), the NDVI vegetation index did not exceed 0.49. In April and May 2018 peak NDVI values for the current year were recorded, reaching a mark of 0.8, however, the vegetation index indicators reflected for 2017 have an advantage and are 0.9. After the above values in the following months, the index underwent a decline in its indicators, and in the final result, in July, the values decreased to 0.25 , which is connected with the harvesting of this crop in the region, the indicators of the previous year for this period again register the predominant position and make up 0.32 . In the further period of the change observation in the NDVI 
index, the fact of an increase in the index values for 2018 compared with 2017 is recorded, and during the 8th month of the research the indicators intersect at 0.28 in their values, after which the prevalence of the vegetation index of 2018 is reflected in relation to the previous year of the research throughout the remainder of the study period. The final peak of the results for 2018 is fixed at 0.59 , registered in December of this year, which is higher by 0.14 points compared to 2017 (NDVI $=0.45$ ). The final data obtained at the end of the 52nd week indicate the convergence of values for both study periods, and reflect the following results: in 2018, NDVI $=0.56$, in 2017 , NDVI $=0.52$.

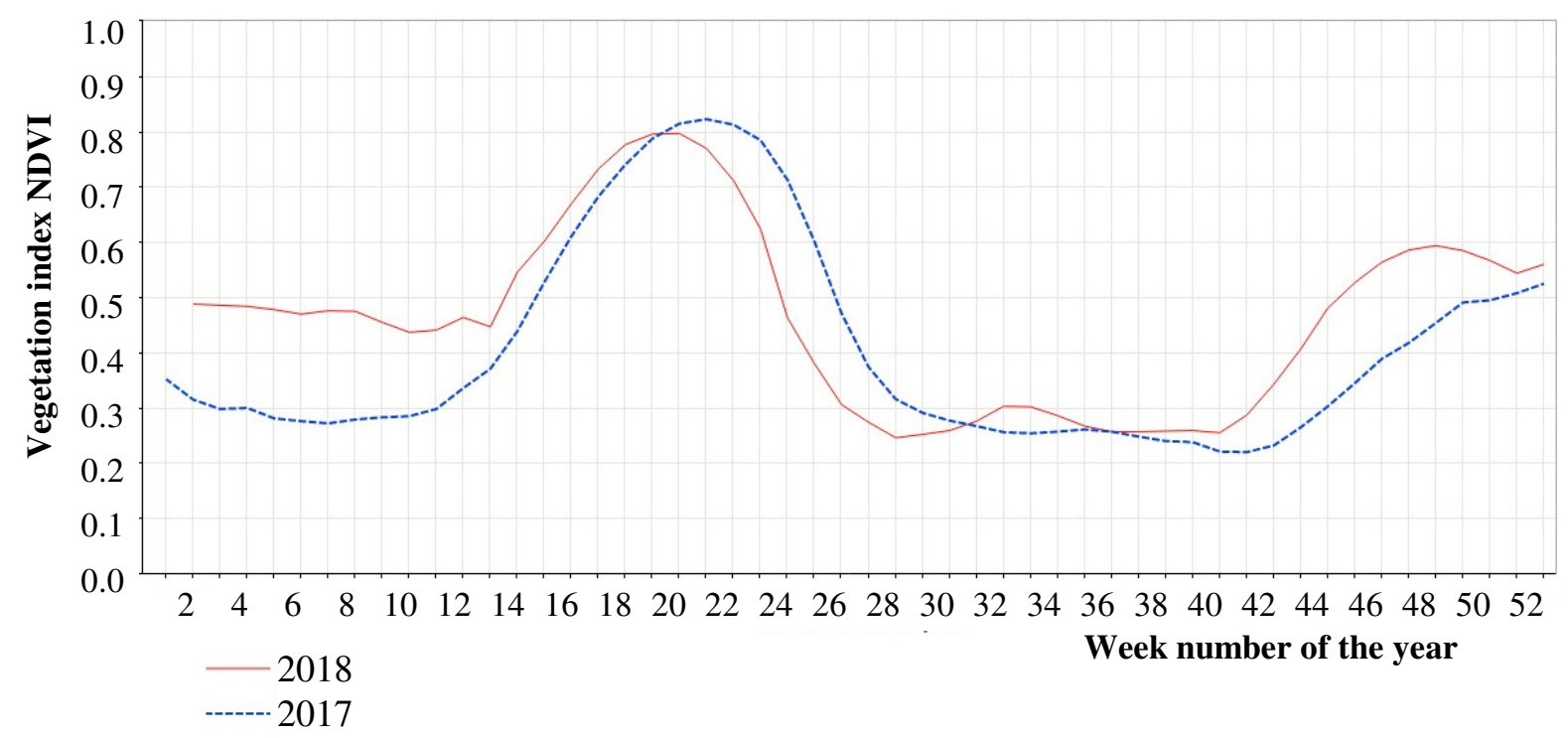

Fig. 1. Dynamics of change in NDVI values: the Stavropol territory NDVI, MODIS (interpolation) regional average (lands occupied by winter crops) are shown for 2018 and 2017

In the final analysis the NDVI vegetation index for 2018 showed better results in terms of 2017, and as a result of these observations, there is a possibility of predicting the yield of the studied crops depending on the administrative, territorial, soil and climatic conditions of the region, as well as on the presence of water erosion processes in the studied areas.

At present, a large number of satellites are presented that conduct continuous monitoring of the land resources state. For effective detection and analysis of water erosion processes, data from the satellites of the American company Digital Globe were used, such as: QuickBird, WorldView 1-3, GeoEye, Ikonos. Their total shooting performance is 3 million $\mathrm{km} 2 /$ day. These satellites belong to the class of commercial and allow to receive images with a resolution of $0.31-4 \mathrm{~m} / \mathrm{pixel}$, while covering a wide spectral range from visible to infrared radiation. In this work, we used archival space images of 2015 on the territory of the Stavropol region.

There are global climate changes that have their own regional characteristics. So, in the Stavropol Territory over the past 58 years significant changes in mean annual air temperature $\left(+1.1^{\circ} \mathrm{C}\right)$ and annual precipitation $(+40 \mathrm{~mm})$ have been revealed. An increase in the frequency of precipitation in the period of May-June is observed, which contributes to development of water erosion processes due to formation of intense surface runoff.

The regime of runoff depends on the amount of precipitation, shape of the relief, structure of the soil and its infiltration abilities, vegetation cover, nature of land use and other factors. The effects of water erosion may vary. In areas with small steepness of the slopes, planar losses of the upper part of the humus horizon occur, and with an increase in the slope steepness, scours, ravines and beams are formed, which are decoded with a high degree of accuracy on satellite images. According to the data of space imagery, linear manifestations of water erosion can be detected most effectively when there are no crops on the fields. The decoding of arable land borders and erosion processes was carried out on the basis of direct interpretation signs. At the initial stage of the research, the area of agrolandscapes in the region specified according to the 2015 space survey data totaled 4,074.2 thousand hectares, which is 332.2 thousand hectares more than the official statistics. The 
difference in arable land indicates the obsolete statistical data or the illegal plowing facts of sloping lands that were used as hayfields and pastures.

As a result of the images decryption, it was found that the total length of erosion processes throughout the study area is $25,209 \mathrm{~km}$, while $94 \%$ of erosion processes belong to the class of scour and rattles, the remaining $6 \%$ have already passed into the ravine and gully stage and were removed from agricultural production.

Due to the capabilities of the modern GIS technologies, an arable land area was estimated with different stages of manifestation of linear water erosion processes. It was found that $47 \%$ of arable land or 1931 thousand hectares in the region are subject to this type of degradation to some extent (Fig. 2).

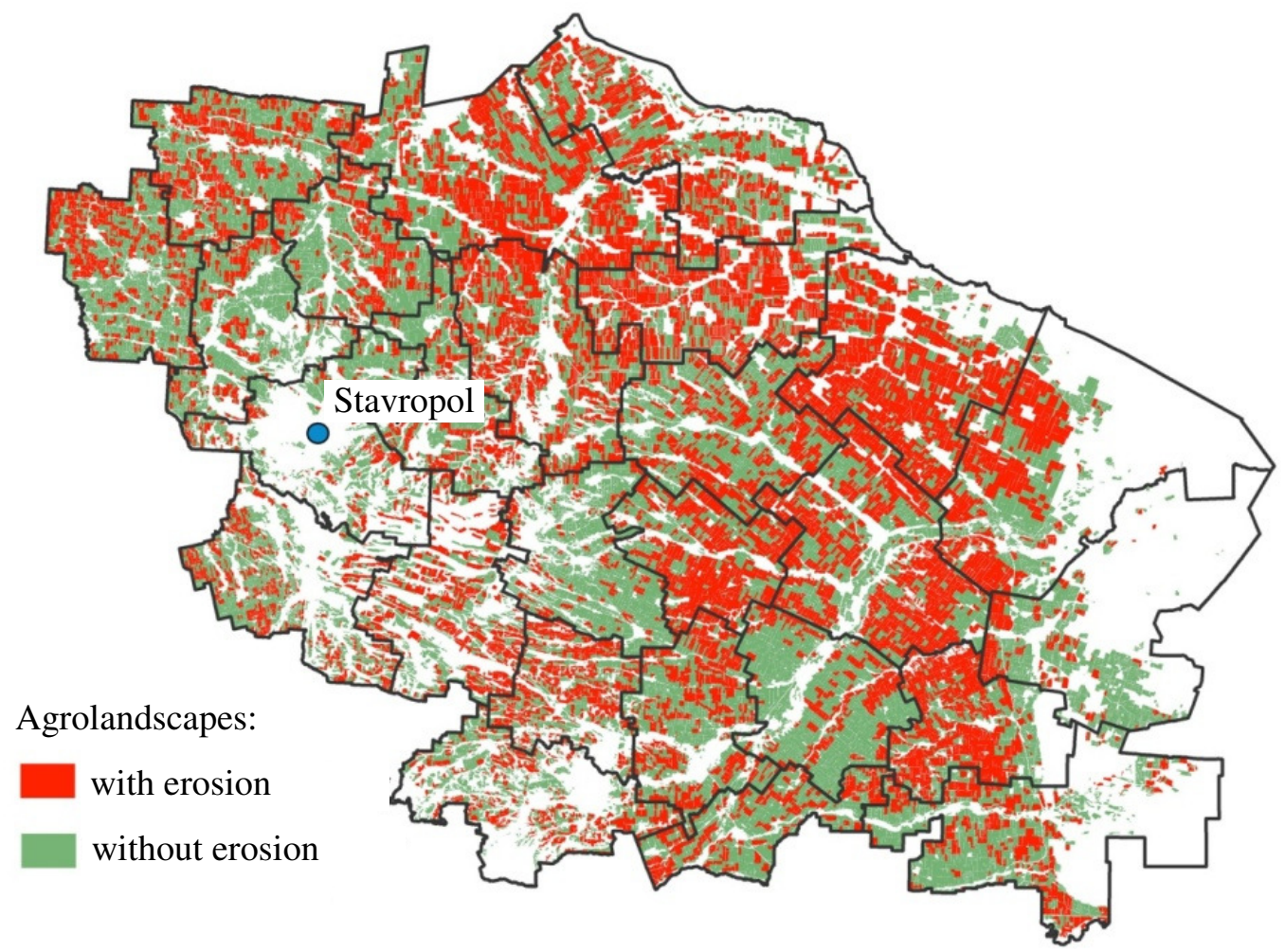

Fig. 2. Linear water erosion in agrolandscapes of Stavropol Territory

Using the radar data (SRTM), a relief digital model of the Stavropol Territory was obtained, on the basis of which the morphometric characteristics of agricultural landscapes were analyzed in order to identify the factors influencing the development of linear water erosion processes. It is established that $78 \%$ of agrolandscapeareas have a slope of less than $1^{\circ}, 21 \%$ of agrolandscape areas have from 1 to $3^{\circ}$ and the most erosion-dangerous slope of more than $3^{\circ}$ is found only in $1 \%$ of the area.

The analysis of the agrolandscape slope exposition showed that the slopes of the southern exposure dominate in the region $-28 \%$, the northern exposure is found in $26 \%$ of the territory, the southern $-23 \%$ and the eastern $-23 \%$.

Spatial overlay of the identified processes of linear water erosion and morphometric characteristics of the territory did not allow to unequivocally establish their separate influence on development of erosion processes, which is possibly due to the presence of the erosion-resistant framework in the form of forest belts in the Stavropol Territory.

The statistical analysis made it possible to establish a statistically significant relationship (5\% significance level) between the intensity of linear water erosion and a number of factors, among which, the slope of the area (more than $1^{\circ}$ ), the correlation coefficient 0.74 ; southern slope exposure $(r=0.59)$ and chestnut soils $(r=0.56)$. The multifactor analysis of the cumulative effect of these factors on the development of water erosion processes showed a slight decrease in the multiple correlation coefficient $(r=0.49)$, but it is statistically significant. 
The existing anti-erosion carcass of forest belts in the Stavropol Territory loses its effectiveness every year, which is due to their natural death or human economic activity. The analysis conducted on the basis of randomized sampling of plots showed that in most of the region (70 \%) the direction of the existing forest shelter belts coincides with the direction of the flow line. The conducted field observations found that placing the boundaries along the flow line or at an angle to the horizontals the soil losses along the boundaries can reach catastrophic values (up to 5,600 $\mathrm{t} \cdot \mathrm{ha} \mathrm{h}^{-1}$ ), forming deep erosion and ravines. The placement of fields with a long side along the slope contributes to the plane water erosion development and hollow formation.

On the basis of a digital elevation model using geo-information technologies, watercourses were modeled in the study area. As a result of the imposition, the resulting model and the identified erosion processes, and their coincidence were established in individual areas, which indicates their high degree of erosion hazard, a total of 382,326 hectares of such territories were identified. In these territories the existing anti-erosion carcass is either completely destroyed or ineffective. In this regard, it is necessary to make an inventory of forest shelter strips to assess their effectiveness and develop measures for anti-erosion arrangement of the territory.

Different types of degradation in varying degrees reduce the productivity of agricultural crops. Salinity and alkalinity decrease by $55 \%$ to the greatest extent, water erosion $-19 \%$, deflation $-13 \%$, flooding $-6 \%$.

\section{Conclusions}

1. On the basis of the obtained data, it can be concluded that the NDVI index undergoes a change in the direction of increasing and decreasing its indicators, both during the current research period and during the previous year.

2. It has been established that water erosion as a whole along the territory by 2026 can lead to a loss of 700 thousand tons of grain of the main crop in the region, winter wheat. Modern technologies, such as space imagery and GIS technologies, allow you to effectively and quickly identify and analyze erosion-hazards. The combination of high-resolution remote sensing and mediumresolution data has shown maximum efficiency for analyzing the development of linear water erosion processes. The development of a comprehensive program of erosion control measures will save up to $10 \%$ of the future crop in the Stavropol Territory.

\section{References}

[1] Vlasova O.I., Perederieva V.M., Volters I.A., Tivikov A.I., Trubacheva L.V. Change in microbiological activity under the effect of biological factors of soil fertility in the central Ciscaucasianchernozems. Biology and Medicine. No. 7 (5), 2015.BM-146-15.

[2] Tskhovrebov V.S., Faizova V.I., Mar'in A.N., Novikov A.A., Nikiforova A.M. Changing in ammonifiers of virgin land and chernozemsploughland to Central Ciscaucasia. Research Journal of Pharmaceutical, Biological and Chemical Sciences, 7 (4)., 2016. pp. 2174-2177.

[3] Tskhovrebov V.S., Faizova V.I., Mar'in A.N., Kalugin D.V., Novikov A.A. Document Changing population by aerobic nitrogen-fixing bacteria in natural and anthropogenically transformed chernozemsbiogeocenoses Central Ciscaucasia. Source of the Document Research Journal of Pharmaceutical, Biological and Chemical Sciences.7 (4)., 2016. pp. 2178-2182.

[4] Trukhachev V.I., Sklyarov I.Y., Sklyarova Y.M., Gorlov S.M., Volkogonova A.V. Monitoring of efficiency of Russian agricultural enterprises functioning and reserves for their sustainable development. Montenegrin Journal of Economics. 14(3)., 2018. pp. 95-108.

[5] Trukhachev V.I., Sklyarov I.Y., Sklyarova Y.M., Mazloev V.Z., Volkogonova A.V. Features of investment activity in agriculture in the south of Russia and ways of its activation. Montenegrin Journal of Economics. 14(1).,2018. pp. 171-184.

[6] Esaulko A.N., Sigida M.S., Golosnoy E.V., Ozheredova A.Y., Korostylev S.A. Management Of Nitrogen Fertilizing Of Winter Wheat In No-Till Technology. Research journal of pharmaceutical biological and chemical V. 9. I. 6., 2018. pp. 1916-1920.

[7] Trukhachev V.I., Esaulko A.N. Antonov S.A, Loshakov A.V., Sigida M.S. Water Erosion Monitoring On The Territory Of Agrolandscapes Stavropol Territory By Remote Methods. 
Research journal of pharmaceutical biological and chemical sciences.V. 9. I. 6., 2018. pp. 17661769.

[8] Loshakov A., Shevchenko D., Kipa L., Kasmynina M., Malykhina T. Quality Monitoring of The Agricultural Land In The Stavropol Region.Research journal of pharmaceutical biological and chemical sciences.V. 9. I. 4., 2018. pp. 897-901.

[9] Pismennaya E.V., Loshakov A.V., Odinsov S.V., Stukalo V.A., Improving Model of Territorial Organization of Agricultural Land Tenure. Research journal of pharmaceutical biological and chemical sciences.V.7. I. 6, 2016. pp. 1783-1787.

[10] Han Z., Zhong S., Ni J., Shi Z., Wei C. Estimation of Soil Erosion to Define the Slope Length of Newly Reconstructed Gentle-Slope Lands in Hilly Mountainous Regions. Scientific Reports. 9(1), 4676. 2019.

[11] Kanjir U., Duric N., Veljanovski T. Sentinel-2 Based Temporal Detection of Agricultural Land Use Anomalies in Support of Common Agricultural Policy Monitoring. ISPRS International Journal of GEO-Information. V.7. I. 10, 2018. N. 405.

[12] Boldyreff A.S., Nosko O.E., Belyaev A.O. High-performance Monitoring System of Agricultural Land with Unmanned Aerial Vehicles as the Main Element of Precision Farming. Conference on Emerging Imaging and Sensing Technologies for Security and Defence III; and Unmanned Sensors, Systems, and Countermeasures. Berlin, Germany. SEP 12, 2018. V.10799.Article number UNSP 107990V. 2018.

[13] VEGA-Science.Unique scientific complex "BS IKI-Monitoring”[online][16.02.2019] Available at: http://sci-vega.ru/

[14] Storchak I.G.,Eroshenko F.V. Assessment of winter wheat yield in the Stavropol region using NDVI. TwelfthAll-RussianOpenConference"Modern Problems of Remote Sensing of the Earth from Space" Space Research Instituteof the Russian Acamedy of Sciences, Moscow, 2014. 387 p. 